\title{
Gertrude/Ophelia:
}

\section{Feminist Intermediality, Ekphrasis, and Tenderness in Hamlet}

Sujata Iyengar

University of Georgia

Did Gertrude drown Ophelia? To a Shakespearean, the question seems absurd, yet students and readers ask it repeatedly in class and online in fan-sites such as Shakespeare Geek, or in response to the amateur video artists who upload versions of Shakespeare's Hamlet in which the hero's vindictive mother drowns his innocent love. ${ }^{1}$ It might be tempting to dismiss such attempts as crowd-sourced ignorance, but if we pay fan culture the compliment of taking it seriously, it can teach us something new about the plays and speeches that we think we know well. Moreover, as early as 1805 Shakespearean editor E.H. Seymour asked why Gertrude did not save Ophelia instead of watching her drown and listening to her old lauds or old tunes. ${ }^{2}$ The young women (or users who self-identify as women online) who accuse Gertrude of murdering her potential daughter-in-law are responding to Gertrude's characterization in the play as what we might call a culpable “ekphrast.” Analyzing Gertrude’s best-known and widely anthologized

I thank Chris Eaket and Dan Fischlin for enriching my understanding of intermedia, and Susan Rosenbaum and the editors of this volume for their astute comments on this essay.

${ }^{1}$ Shakespeare Geek, “Ophelia Was Pushed!”, modified March 10, 2010, accessed May 31, 2013, http://blog.shakespearegeek.com/2010/03/ophelia-was-pushed.html; Mustachio Shakespeare, "Gertrude Kill Ophelia," accessed May 31, 2013, http://www.youtube.com/watch?v=4PXvstuKMGk; see also Sujata Iyengar and Christy Desmet, "Rebooting Ophelia: Social Media and the Rhetorics of Appropriation," in The Afterlife of Ophelia, ed. Kaara Peterson and Deanne Williams (Basingstoke: Palgrave, 2012), 71.

${ }^{2}$ E. H. Seymour, "Scene VII," in Remarks, Critical, Conjectural, and Explanatory, upon the Plays of Shakespeare (London: Printed by J. Wright, for Lackington, Allen \& co. [etc.] 1805), 197-8, Google Books, accessed June 4, 2013. 
speech — her floral eulogy to the drowned Ophelia — and building on Laura Mulvey's influential essay about the "male gaze" of the camera in classic Hollywood cinema, Martha Ronk argues that Gertrude occupies a male, ekphrastic subject-position and that she frames the dead girl as analogous to the subject of a painting, aestheticized, sanitized, objectified, and restrained into art, as she attributes overwhelmingly to the dead girl the quality that Mulvey calls "to-belooked-at-ness." ${ }^{\text {R }}$ Ronk suggests that some readers encounter Gertrude's speech as an admission of guilt — or at least, as a failure to save Ophelia — because the text establishes a distantly voyeuristic subject-position for the queen, one that evokes no "maternal intimacy" such as that later implied by Gertrude's expressed wish to have cast flowers on Ophelia's marriage-bed, rather than her grave. ${ }^{4}$

Ronk's reading corresponds to Elaine Showalter's pioneering essay arguing for a feminist approach to Shakespeare's Ophelia that "reads" her not through Shakespeare's play but through the appropriations of this character developed by the early psychiatrist Jean-Martin Charcot and by artists such as those of the Pre-Raphaelite Brotherhood. Showalter outlines three earlier feminist approaches to understanding Ophelia: as a girl subordinated by the older men and authority figures around her; in Lacanian terms, as a Woman deprived of language by the workings of the Symbolic Order; and, in archetypal terms, as the repressed anima or female half of Hamlet, able to express what is unutterable by protagonist or playwright. Showalter finds each of these approaches to be limiting; she argues that the most nuanced way for a feminist critic to study Ophelia is through the study of the appropriations or adaptations of this character. Since critical commentary is by its nature restricted by the historical and social position of the writer, she suggests, we can only access the multiple potentialities in the character of Ophelia by

${ }^{3}$ Laura Mulvey, "Visual Pleasure and Narrative Cinema," in Screen 16.3 (1975): 6-18, reprinted in Feminisms: An Anthology of Literary Theory and Criticism, ed. Robyn Warhol-Down and Diane Price Herndl (New York: Rutgers University Press, 1997), p. 442. 
historicizing the ways in which artists and critics use her. Showalter concludes with an analysis that carries out this plan, one that considers the representation of Ophelia in visual art, from the ardent brush-strokes of the pre-Raphaelites to the clinical photographs of Jean-Martin Charcot, as an index to cultural attitudes surrounding female "hysteria" or madness. ${ }^{5}$

Both Showalter and Ronk identify the framed and aestheticized Ophelia as a cipher or a victim or a lacuna, inaccessible as a subject except through the work or vision of male observers whom feminist critics must carefully historicize. In the twenty-first century, however, perhaps inspired by Mary Pipher's popular psychology book Reviving Ophelia and its off-shoots such as Cheryl Dallasega's Surviving Ophelia and Nina Shandler's Ophelia's Mom, both from 2001, we see women and girls re-imagine Ophelia as a speaker and a subject. ${ }^{6}$ Ophelia additionally appears in women's art all over the world, including in non-Anglophone countries, as an instantly recognizable icon, the subject, for example, of exhibitions in Kerala in 2007, Amsterdam in 2008, Hong Kong in 2012 and many others. It is perhaps now time to generate a fifth approach to Ophelia, one that considers the material and social contexts of late-twentiethand early-twenty-first-century appropriations of Ophelia by women and girls as indices to changing global attitudes towards auto-eroticism and overt sexual display. To what extent do such fine art and social media representations of Ophelia by women merely reiterate the "phallic" or objectifying gaze identified by Mulvey or the attribution of hysteria to girlhood identified by Showalter? Differently put, if woman artists depict Ophelia, do they necessarily become culpable ekphrasts (as Ronk suggests Gertrude is) or does the self-conscious, self-

\footnotetext{
${ }^{4}$ Martha Ronk, "Representations of Ophelia," Criticism 36.1 (1994): 30.

${ }^{5}$ Elaine Showalter, "Representing Ophelia: women, madness, and the responsibilities of feminist criticism," in Shakespeare and the Question of Theory, ed. Patricia Parker and Geoffrey Hartman (London and New York: Routledge, 1985), 77-94.

${ }^{6}$ Mary Pipher, Reviving Ophelia: Saving the Selves of Adolescent Girls (New York: Putnam, 1994); Sara Shandler, Ophelia Speaks (New York: HarperCollins, 1999); Nina Shandler,
} 
identification of the artist as feminist (on the one hand) or the supposedly demotic medium of Web 2.0, with its user-generated content (on the other) make a difference?

Feminist artists and filmmakers have long examined in what ways (if any) artists can represent women's experience, art, and lives without objectifying the women they portray. In what follows I will suggest that by examining representations of Ophelia by women (or creators self-identified as female, in the case of online avatars) in the twenty-first century through theories of intermediality we can explore the following questions: under what circumstances might we imagine femininity as essential, constructed, or contingent and in between? Can the subject of an artwork express a kind of selfhood or is such a subject invariably objectified through being turned into art? Can artists' ironic use of sexist tropes interrogate such tropes without reinforcing them? Major theoretical concerns in feminist studies emerge as we consider such representations, which include the mixed media of pop artist Jann Haworth, the watercolors of Ann Arnold, the harsh lithographs of Louise Bourgeois, the witty oil-paintings of Ophelia Redpath, the intermedia "bacterial painting" and associated telephone poetry of Jo Wonder, the conceptual and book art of Eugénia Balcells, Margot Ecke, or Ophelia Chong, the sculptures of Kiki Smith, Liza Lou, or Liz McGrath, and the many photographic and computer-edited intermedia self-portraits as Ophelia that are visible in traditional exhibition spaces and also on social networking cultural production sites such as Flickr, Pinterest, Etsy, DeviantArt and other venues where artists blur the boundary between social and professional cultural production (since many creators are paid by other users for copies of their content).

It helps at the outset to use the term intermediality rather than "ekphrasis" or even "interarts theory." "Ekphrasis" properly refers to the description of one work of art within another (W.H. Auden's poem "The Shield of Achilles" is often cited as an example). "Inter-arts studies"

Ophelia's Mom (New York: Crown, 2001); Cheryl Dellasega, Surviving Ophelia (Cambridge, 
has extended the work of ekphrasis to multi-media art forms (looking at, for example, the representation of music within novels, of text within paintings, and so on), but, as Irina Rajewsky helpfully argues, inter-arts studies has neglected the specific material forms of cultural productions. Intermediality accounts for and fills in this ellipsis. Jens Schröter distinguishes among synthetic, formal, transformational, and ontological intermedialities, but Rajewsky offers both a narrower and a broader definition for literary critics. ${ }^{7}$ Her general explanation defines intermediality as

a generic term for all those phenomena that (as indicated by the prefix inter) in some way take place between media. "Intermedial" therefore designates those configurations which have to do with a crossing of borders between media, and which thereby can be differentiated from intramedial phenomena [what Schröter would call "transformational intermediality"] as well as from transmedial phenomena (i.e., the appearance of a certain motif, aesthetic, or discourse across a variety of different media [what Schröter calls formal or transmedial intermediality]. ${ }^{8}$

Rajewsky's expansive definition of intermediality fits most closely Schröter's "synthetic" intermediality, a blurring between and among media that creates in itself a new medium or art form. Rajewsky also develops stricter categories of intermediality: "The first concentrates on intermediality as a fundamental condition or category [this would be Schröter's “ontological intermediality"] while the second approaches intermediality as a critical category for the

MA: Perseus, 2001).

7 Jens Schröter, "Four models of Intermediality," in Travels in Intermedia[lity] : Reblurring the Boundaries, ed. Bernd Herzogenrath (Hanover, N.H. : Dartmouth College Press, 2012), 15-36. ${ }^{8}$ Irina O. Rajewsky, "Intermediality, Intertextuality, and Remediation: A Literary Perspective on Intermediality,” in Intermédialités 6 (2005), 45-6, accessed November 22, 2013. 
concrete analysis of specific individual media products or configurations." ${ }^{.9}$ It is this last definition that Rajewsky finds most helpful for literary study, particularly as, she insists, we must continue to historicize the specific materializations of media within the arts even as we identify such arts as intermedia and theorize them.

In what follows I will shine both the broad and the narrow beams of intermedia theory upon representations of Shakespeare's Ophelia in women's art. I will argue that on the one hand, the figure of Ophelia in some of the artworks produced does seem to give women and girls explicitly feminist avenues for self-expression and self-realization by deploying a primary or fundamental intermediality: they present Ophelia as self-creating artist, not just as artifact. Others, however - because of the material contexts in which they are created and disseminated — reiterate the culpable ekphrasis that Ronk finds in Gertrude's speech and that Showalter finds in the pre-Raphaelites' paintings and Charcot's photographs of hysterics. Finally, I will revisit Gertrude's speech itself, arguing that the speech's frequent appearance in anthologies, sans textual apparatus, masks its potential for multiple meanings and, in particular, for a subjectposition for Gertrude as a loving mourner rather than a voyeuristic viewer. If, however, we consider textual variants, both accidental and substantive, within the text, we can locate spaces for tenderness and interactivity in Gertrude's elegiac speech, which presents both Gertrude and Ophelia as artist and object and attests to the complex, non-binary solutions available to women artists as they seek to represent themselves and each other in their arts.

\section{From Culpable Ekphrasis to Capable Intermediality}

${ }^{9}$ Rajewsky, 47. 
Ronk identifies as culpable ekphrasis the guilty gaze of a Gertrude who observes and aestheticizes the dying Ophelia. Formally, culpable ekphrasis frames the subject (within a literal picture frame or within the confines of iambic pentameter), displays the woman's body as a manufactured object independent of the observer, and demonstrates its beauties to a third-party observer, often implicitly male. Laura Mulvey has called this voyeuristic effect the "male gaze" and suggested that the quality of such representations connotes for women's bodies the quality of "to-be-looked-at-ness." We might also object that such a frame restricts what Ophelia's body can "say" by turning it into one kind of art -- a monomedium -- and denying what, using Schröter's terms, we might assert is its primary or ontological intermediality. Ophelia's body within the speech can serve not only as a monomedium or bearer of cultural values about womanhood but also as a reminder of the intermediality of women's bodies themselves. To adapt Showalter's formulation of a "Cubist" Ophelia who exists in fragments, an intermedia Ophelia exists among the bodies of the boy-actors who play both Ophelia and Gertrude in the early modern period and the female actors who play them after the Restoration; the spoken and printed words heard, seen, and read about her; the traditional or classical paintings of her; and in more recent explicitly multimedia iterations. Even when read in Folio or Quarto, Ophelia in Gertrude's speech exists as intermedia, not merely ekphrasis, evoking as it does what Harry Berger, Jr. has called the "imaginary audition" of Shakespeare's plays ${ }^{10}$ (and, in a second-order focalization, an image within an image as we hear Gertrude make and re-make Ophelia).

Describing Ophelia as the object of a "gaze" is therefore less helpful than imagining how a mutual or collaborative endeavor among performers, readers, viewers, and artists might bring her to life. Andrea Liss retains Mulvey's term "gaze," but calls this collaborative mutuality a "maternal gaze," one that she identifies in Mulvey and Peter Wollen's own experimental film

${ }^{10}$ Harry Berger, Jr., Imaginary Audition: Shakespeare on Stage and Page (Berkeley: University 
Riddles of the Sphinx.${ }^{11}$ For Liss, this mutuality recalls and prefigures the intersubjective and pleasurable combination of breastfeeding an infant and reading a book in a completely melded form of intellectual, engaged maternity. ${ }^{12}$ Liss argues that to foreground the maternal in art is not to risk essentializing or reifying maternity but to engage more fully with its nuances. Citing the philosopher Sarah Ruddick, she deploys the word "mothering" as both a noun and a verb, "gender-full and gender-free." ${ }^{13}$ In a chapter on photographer Gail S. Rebhan's black-and-white images of her growing sons, Liss identifies aspects of the maternal in representations of children — one's own, or others'; in another, she considers women's usually undocumented domestic work as cultural production. Finally, Liss addresses maternal mourning in May Stevens' griefstricken tributes to her dead photographer-son through re-appropriations of her son's own work in Stevens' own. Feminist maternal elegy, Liss concludes, makes sacred the creative work of mothers and children together.

Although Liss writes specifically about the maternal in the work of individual artists, I would suggest that we can extend her notions of both the maternal and of the feminist. Ruddick's "gender-full and gender-free" mothering, a care-full love or power-sharing that humans of any gender or maternal status can extend to each other, connects obliquely to Martha Nussbaum's model of "capabilities feminism" in Women and Human Development. ${ }^{14}$ A capabilities approach asks democracies to affirm ten core human capabilities: life, bodily health, bodily integrity, senses, imagination, and thought, emotions, practical reason or critical reflection, affiliation, other species, play, and control over one's environment. Capabilities feminism critiques

of California Press, 1990), 74-103.

${ }^{11}$ Andrea Liss, Feminist Art and the Maternal (Minneapolis and London: University of Minnesota Press, 2009), 16; Laura Mulvey and Peter Wollen, dirs., Riddles of the Sphinx (1977).

12 Liss, 74-5.

${ }^{13}$ Liss, 67.

${ }^{14}$ Martha Nussbaum, Women and Human Development: The Capabilities Approach (Cambridge: Cambridge University Press, 2001). 
measurements of economic well-being that rely upon gross national product or measures of output without taking into account the activities that engender these products or measures and their impact on women (for example, a capabilities approach might find common cause with labor activists who note the unpaid domestic labor of working women as an invisible or unmeasured factor in an industrialized country's economy). ${ }^{15}$ Nussbaum's feminist work has proven controversial because it generates a normative list at all, because it privileges a list of Euro-centric capabilities, because it places physical well-being above spiritual integrity, and because it refuses to preserve cultures for their own sakes or for the sake of history (although her recent book The New Religious Intolerance goes some way towards countering these charges). ${ }^{16}$ Some feminist theorists who incline more towards the social constructivist side of the spectrum (such as Judith Butler) identify capabilities feminism as neo-liberal or essentialist. I am comfortable deploying a strategic or delimited essentialism within this essay in part because the nature of intermedia representation demands material, historical, nuanced specificity in each instance. In other words, even as I am drawing broad ontological conclusions about what feminist intermedia art might be, I am doing so by distinguishing finely among artworks and artists and their material contexts.

"Maternal" artistry or feminist intermediality (a phrase I'd prefer and that I will use from now on) in this sense could encompass all compassionate human subjects who try to understand, access, or represent each other through art and a given society's support of women's artistry and labor (and here I'm returning to Liss's suggestion that we reimagine or reframe women's ofteninvisible domestic work as artistic process). What Liss calls "maternal art" or Elizabeth

${ }^{15}$ Ingrid Robeyns, "The Capability Approach," in The Stanford Encyclopedia of Philosophy (Summer 2011 Edition), ed. Edward N. Zalta, accessed March 24, 2014.

2011.

${ }^{16}$ Martha Nussbaum, The New Religious Intolerance: Overcoming the Politics of Fear in an Anxious Age (New York: Belknap Press, 2013). 
Bergmann Loizeaux calls "feminist ekphrasis" or "ethical ekphrasis" are sub-species of feminist intermediality, engagements in cultural production that "[recognize] that a woman's place as viewer is established within, beside, or in the face of a male-dominated culture, but that the patterns of power and value implicit in a tradition of male artists and viewers can be exposed, used, resisted, and rewritten"; ${ }^{17}$ such cultural productions can be created by both men and women, although Loizeaux's essay concentrates upon the "ethical ekphrasis" of Marianne Moore and the historical ekphrasis of Adrienne Rich. The traits of "nonpredatory looking," self-parody and self-restraint, and the expression of a moral point of view that Loizeaux finds in Moore's poetry — what Moore herself calls, using the imagery of light and eyesight, "re-vision," 18 correspond, perhaps, to the mutually constitutive, collaborative gaze that Liss identifies in maternal art. Similarly, Rich's inter-artistry or intermediality, which generates both a women's history (a history OF women) and a women's historiography (a history BY women), "invokes the work of art's presence as evidence," ${ }^{\prime 19}$ celebrates the subject of art as an artist in her own right, just as, we might suggest, feminist intermediality incorporates another person's creative presence in the new artwork.

To this synthesized list of what might constitute a feminist intermediality I would add a number of formal characteristics that will emerge as we look at women's late twentieth and early twenty-first representations of Ophelia. Kaara Peterson and Deanne Williams observe in the introduction to their recent essay-collection The Afterlife of Ophelia that twentieth- and twentyfirst-century Ophelias in art and photography tend toward the "meta-representational," to comment upon their own status as artwork and to contextualize themselves as part of a tradition

${ }^{17}$ Elizabeth Bergmann Loizeaux, "Women Looking: The Feminist Ekphrasis of Marianne Moore and Adrienne Rich," in In the Frame: Women's Ekphrastic Poetry from Marianne Moore to Susan Wheeler, ed. Jane Hedley, et al., 121-144 (University of Delaware Press, 2009), 122.

${ }^{18}$ Quoted in Loizeaux, 131.

${ }^{19}$ Loizeaux, 134. 
of women's appropriation of Shakespeare. ${ }^{20}$ Remedios Perni's essay on contemporary photography in the same volume further suggests that the work of contemporary women photographers deploys "the marginality" of Ophelia "creatively...to emancipate female subjects." ${ }^{21}$ Feminist intermediality in these artworks often chooses to portray a subject who is youthful, relative to the artist; exhibits a certain tenderness of approach, whether in the position of the subject, the color-scheme, or the medium; interests itself in the domestic or small-scale in either the content of its imagery or in its literal size, or both; and imagines stories and scenes from outside the frame of Shakespeare's words. I also include a material (some might say, a materialistic) criterion. Adapting Woolf's germinal pronouncement that "A woman must have money and a room of one's own if she is to write fiction," we can measure the success of "feminist movement" (to quote bell hooks' antithemeria in Feminist Theory) ${ }^{22}$ by whether women are able now, nearly ninety years after Woolf, financially to survive through making feminist art. Indeed, in my adaptation of capabilities feminism, for art to succeed as feminist art, it must enable its practitioners to make a living or at least to supplement financially an artist's income; both the art and the environment that produces it must mutually support each other and tend towards the full realization of human capabilities. For this reason, I restrict my analysis below to the work of self-identified, professional female and feminist painters, photographers, digital artists, and sculptors. ${ }^{23}$ This distinction is perhaps the most controversial aspect of my

${ }^{20}$ Kaara Peterson and Deanne Williams, "Introduction," in The Afterlife of Ophelia, ed. Kaara Peterson and Deanne Williams (Basingstoke: Palgrave, 2012), 3.

${ }^{21}$ Remedios Perni, "At the Margins: Ophelia in Modern and Contemporary Photography," in The Afterlife of Ophelia, 198-9.

${ }^{22}$ bell hooks, Feminist Theory: From Margin to Center (London: Pluto Press, 2000), 34.

${ }^{23}$ For a wonderfully detailed and sensitive account of fan- or amateur-generated images of Ophelia online on Flickr and other photo-streams, see Alan Young, "Ophelia and Web 2.0" $<\mathrm{http}$ //www.opheliapopularculture.com/home/ophelia-essay-title-page/ophelia-essay-section5\#Nbref39>, accessed June 1, 2013; for fan-fiction and Ophelia on YouTube, see Iyengar and 
argument here about feminist aesthetics. Women have, obviously, always made art in the domestic or amateur realm, and such art has historically been relegated to the realm of "craft" or "housework." But here I take as axiomatic the union cry of "We want bread, and roses too" -- in other words, I place self-actualization, dignity, and the aesthetic not at the top of a pyramid of human needs but at the center of overlapping circles of what we need to be human -- including physical and financial sustenance. I maintain that if women can now make their lives and livings through feminist art, feminist art is finally beginning to become possible.

\section{Gertrude Paints and Prints Ophelia: The 1970s and 1980s}

During the 1970s and 1980s a group of male and female English artists retreated from the increasingly conceptual and abstract London art world to the countryside, styling themselves (in emulation of both the Pre-Raphaelite Brotherhood and of Samuel Palmer's Brotherhood of Ancients) The Brotherhood of Ruralists. Later known for their cover designs for Methuen for the Arden Shakespeare, second series, the Ruralists agreed that their first joint major exhibition should comprise a series of paintings, drawings, and sculptures on Shakespeare's Ophelia. Describing these images in sequence foregrounds a contrast between the men's images and the women's. Peter Blake exhibited Ophelia in two states, each of which emphasized the character's encounter with sexual violence. The first recalls Ophelia's own words about her encounter with Hamlet in her closet, his "doublet all unbraced," his face pallid and "piteous," "perus[ing her] face / As he would draw it," but in this painting it is Ophelia herself, semi-nude, hair disheveled,

Desmet, op. cit. Work in progress by Ariane Balizet also notes bridal portraits with brides posted as Ophelia on the social curation network Pinterest as part of a phenomenon called the "trash the dress" photoshoot. 
who gazes fixedly upon the viewer. ${ }^{24}$ The later state partly clothes Ophelia in a torn blouse; her nose is bloodied, and she holds a bedraggled bunch of flowers. She still directs her uneven gaze unflinchingly towards the viewer. David Inshaw's eerie The River Bank (Ophelia) depicts two female figures in a highly manicured and pollarded English garden. One is fleeing, with her hands holding on to her broad-brimmed hat; the other lies drowned in the river. The postmodern hyper-realistic style, with vivid colors and granular detail on, for example, the petals of an iris, elongates and twists the women's bodies, the clothing of the drowned girl, and the shapes of greenery in a way that makes it hard for us to know whether we are seeing Gertrude (or a ladies'maid) discovering Ophelia's corpse, or Ophelia herself in both past and present, both contemplating suicide and achieving it. Graham Ovenden rendered his Ophelia (1979-81), like Inshaw's, in oil, but unlike Inshaw's, Ovenden's painting suggests the deceptive simplicity of commercial art (such as an album cover, or a poster). A blonde, teen or 'tween-aged girl, standing against a background of marshy green water and a twilit blue sky with a crescent moon, looks defiantly down her nose at the viewer, holding on to her hair in two bunches. Stylized, tiny, crisp flowers in bright colors are woven into her hair and the buttonholes of her shocking-pink dress. Graham Arnold's Ophelia lies supine on a bed in the ruins of a castle, the outdoor blues and greens and yellows of the sky and earth around her picking up the variegated colors of a patchwork tablecloth beside her. She wears a frilled pinafore dress, like a child, but her mood suggests abandonment, and the assorted objects beside her (a seashell, a folded chess board, a rock, and other traditional subjects for still-lives) hint at a larger, still unexplained mystery.

\footnotetext{
${ }^{24}$ William Shakespeare, Hamlet, ed. Barbara Mowat and Paul Werstine, Michael Poston, and Rebecca Niles (Folger Shakespeare Library: Folger Digital Texts, accessed May 28, 2015), 2.1.88-103.
} 
The three women Ruralists, however, emphasized the character's youth and innocence, as noted in the exhibition catalogue. ${ }^{25}$ This tactic allies them with the proto-feminist tradition of Mary Cowden Clarke's “Ophelia: The Rose of Elsinore” in her Girlhood of Shakespeare's Heroines (1851) and, in different ways, with what Liss has called the feminist art of the maternal. ${ }^{26}$ Most conventional, perhaps, is Ann Arnold's watercolor, which presents a thoughtful, girlish figure in a natural setting surrounded by flowers. Where Graham Arnold's child is surrounded by human-made artefacts, however, and displayed supine (although elaborately clothed) to a viewer's gaze, Ann Arnold's belongs to the natural world and controls the display of her own body. She sits pensively on what we assume is the river bank (the water is not seen) against a background of archetypally English downs, hugging her legs and hunching her back as if to hide her developing body from the viewer's gaze. Removing the water from the image translates this young Ophelia away from what Gaston Bachelard termed the "Ophelia complex," the association of beauty, femininity, and water, that eroticizes a passively suffering or abject girlhood, and moves into an alternative, imaginary future. ${ }^{27}$ The eager, blooming energy of Annie Ovenden's child-Ophelia likewise contrasts the sulky, nascent sexuality of Graham Ovenden's teen Ophelia. Annie Ovenden's child-Ophelia, in a crocheted black shawl beneath an ivied tree and bearing a bunch of poppies, forget-me-nots, and other flowers, displays a girlish quest for approval, standing as if posed for a family photograph. Posing her beneath a tree, firmly on her feet, makes her flower-gathering a sign of young exuberance and aesthetic appreciation, rather than a suicidal ideation.

${ }^{25}$ Arnold Wilson, "Paintings and Drawings on the theme of Ophelia by The Brotherhood of Ruralists, July 5-August 2, 1980," Exhibition Catalog (Bristol: City of Bristol Museum and Art Gallery).

${ }^{26}$ Mary Cowden Clarke, "Ophelia: The Rose of Elsinore," in The Girlhood of Shakespeare's Heroines, Vol. 2 (1851; New York: AMS Press, 1974), 183-256.

${ }^{27}$ Gaston Bachelard, Water and Dreams : An Essay on the Material Imagination, trans. Edith R. Farrell (Dallas : Pegasus Foundation, 1983). 
Most innovative, however (and the work of the only Ruralist to identify herself as feminist), is Jann Haworth's art, which anticipates Liss's suggestion that maternal creativity presents the subject multivalently and with candour, but also supports my suggestion that feminist art is powerfully intermedial. With her usual sardonic feminism, Jann Haworth exhibited two pieces, both terracotta and fabric sculptures: Baby Ophelia, an infant's head; and Ophelia, a be-ribboned terracotta mask of an adult face with a haunting expression of extreme emotional release, somewhere between ecstasy and anguish. One way for an artist to escape objectifying her subject can be to represent her in multiple states and in multiple media; in combination, the cherubic infantine head, as smooth and bland and rounded as a marble putto, with the adult mask of tortured femininity tells a story about what we might call, following Judith Butler, the process and history through which Ophelia is "girled." Butler argues that the body itself is a variable or culturally defined boundary and that it is through discourse that gender is fabricated: the exclamation, "It's a girl!" upon a new-born confers sex along with socialization upon the child. ${ }^{28}$ The infant head appears gender-neutral in both material and expression, but the mask features the long hair we traditionally attribute to Ophelia and the floating ribbons that we might associate (and that the Ruralists certainly would) with the customs of girls dancing round a maypole or with braided hair. Moreover, Haworth in particular validated women's work in textiles as valuable artistic production, most famously in her construction of the large cloth sculptures for the cover of the Beatles' Sergeant Pepper but throughout her work on more classical themes, too. As Mark Rappolt notes in the catalog for Haworth's recent retrospective at the Kunsthalle Vienna, "At its root, [Haworth's] move to fabric was an attempt to find a language that could be

\footnotetext{
${ }^{28}$ Judith Butler, Bodies That Matter: Gender and the Discursive Limits of Sex (London and New York: Routledge,1993), xvii.
} 
exclusively her own, and in the process, almost incidentally make her gender a weapon rather than an impediment. ${ }^{29}$

Almost diametrically opposed to the Ruralists' nostalgia, craftedness, and English specificity stand the modernism, photographic processes, and abstraction of Louise Bourgeois. Her disturbing five-color lithograph "Hamlet and Ophelia" (1979) seems to blame an archetypally male Hamlet for Ophelia's death; the faux-naive figure penetrates Ophelia sexually as he appears to push her under the water. The lines and blue color of Ophelia's hair associate her with the waves that pull her under and with the cultural femaleness also indicated by her heavy, black, high-heeled shoes (Hamlet's feet, in contrast, disappear into crude circles, and the signs of his maleness are broadly physiological — an erect and penetrating penis and a protuberant Adam's apple, darkly outlined in black). This is feminist or ethical ekphrasis in Loizeaux's sense, not only because we are called to make a moral judgement upon Ophelia's fate but also because, on a second glance, Hamlet himself turns into victim, like Ophelia. It is also formally and ontologically intermedial, refracting play-text, photography, printing, and what Schröter calls the "life-medium" of the human body. ${ }^{30}$ Hamlet, too, is "out at sea," and the intertwined lines of the lovers' bodies transform them into a single, sinuous movement. The image reminds us that the world of Hamlet polices the sexuality of young people and sexualizes the politics of their elders. Something is rotten in Denmark, and only Bourgeois's water remains free and clean.

But framing death as art is dubiously feminist, even though it does pass a judgement on "ethical ekphrasis." The British artist Ophelia Redpath ignores Ophelia's drowning altogether in their painted reframings of Hamlet. Redpath's witty self-portrait, "I have heard of your paintings," re-appropriates in a mischievous context Hamlet's strictures against women's use of

\footnotetext{
${ }^{29}$ Mark Rappolt, "Jann Haworth," in Power Up: Female Pop Art, ed. Angela Stief (Vienna: Kunsthalle Wien, 2010), 215 col. 1.

${ }^{30}$ Schröter, 19.
} 
cosmetics (and by extension, his implicit critique of female sexual and artistic expression). In this oil on canvas, we see (framed by a heavy brocaded curtain that might cover a painting or, perhaps, a stage) the dungaree'd, barefoot, and beret'd artist sketching William Shakespeare himself, who looks skeptically at her from the corners of his eyes. A large ginger tom nests behind Ophelia, and a tabby arches over the easel; Shakespeare clutches, cautiously, a bound book. The image nods to several iconic early modern artworks through its pose (think of Velasquez painting himself painting, or, even more pertinently, Artemisia Gentileschi's images of herself as "La Pittura," or the allegory of painting) and its technique (the careful perspective of the black-and-white marble tiles upon the floor; the velvet brocade). Technically perfect, its use of humor takes it close to illustration or graphic design, and the close relationship between painting and title (you need to know the name of the painting fully to enjoy the joke) makes its gaze collaborative, mutual, ethical, and historiographic.

\section{Gertrude Sculpts Ophelia}

Just as there is a feminist or proto-feminist tradition of representing Ophelia in girlhood or infancy, starting with Mary Cowden Clarke, so there exists a tradition of sculpting Ophelia in three dimensions, starting with the statues hewn by actress Sarah Bernhardt to "subversive" acclaim. ${ }^{31}$ Alan Young has recently discovered and tracked the changes that Bernhardt made to versions of her marble Ophelia statues, including the way that Bernhardt incorporated aspects of her own physical appearance into the "ecstatic," eroticized sculpture: "By incorporating [her elegant neck] into her sculpture, Bernhardt is able to create a version of the sinuous, serpentine movement of her body that she frequently employed in her death scenes and that is occasionally

\footnotetext{
${ }^{31}$ Alan Young, "Sarah Bernhardt's Ophelia," in Borrowers and Lenders: The Journal of Shakespeare and Appropriation 8.1 (2013), accessed March 24, 2014.
} 
found in portraits of her," writes Young. ${ }^{32}$ After discussing Bernhardt's practice of bringing her own body on stage on a bier as the dead Ophelia, Young suggests that Bernhardt's multi-media representations of Ophelia (as sculpture, as performance, and as performance art) contribute significantly what critics have called a Victorian "necrosexual" cult of femininity and to representations of an eroticized, dead Ophelia that persist today. ${ }^{33}$

Three-dimensional installations, by definition, allow Ophelia to break out of her confining frame. Bernhardt worked in marble, considered a medium literally too hard for a woman to use, but at the turn of the twentieth century, Kiki Smith deploys bronze, South-Africabased American artist Liza Lou crafted an Ophelia of wood, glass, fabric, and hundreds of tiny glass beads, and Liz McGrath gilded and bejeweled a polycarbon head of Ophelia in 2004. Kiki Smith's bronze sculpture of Ophelia recalls the casts of Degas or Rodin (I'm thinking in particular of Degas's Little Dancer or Rodin's Thinker), but unlike the conventionally-posed, large scale, and highly textured bronzes of these artists, her table-top-sized, smooth and girlish Ophelia "lies with her back arched and her legs s[1]ightly raised, as if she were both convulsing and floating." ${ }^{34}$ The figure's nudity and traditionally limniadine locks, her upraised feet and her legs extended as though in levitation, render her not just aethereal but asexually aesthetic, completely self-contained, as a well-wrought urn. In that sense, the "convulsi[ve]" elegance of the figure fits right into the tradition of pathological, beautiful, drowned femininity identified by Showalter. If we call this art "feminist," we do so in Loizeaux's sense, as art that exposes the history of male connoisseurship of the smooth, aestheticized bodies of adolescent girls. In contrast, Liza Lou's Relief (2003), a self-described "riff” on "the Ophelia painting by John Everett Millais," intermediates not only the "Victorian obsession with photographs of dead

\footnotetext{
${ }^{32}$ Young, "Sarah Bernhardt's Ophelia."

${ }^{33}$ Young, "Sarah Bernhardt's Ophelia."
} 
children," "glass reliquaries" and communion rites of practising Catholics but also, through its medium, to the history of women's labor. ${ }^{35}$ Relief presents a wooden Ophelia-doll in a white beaded gown of what seems like silk, on her back in a red box with a blue background. Lou's sculptures feature thousands of tiny, gleaming, glass beads, added in a time-consuming, painstaking process that recalls the work of the impoverished nineteenth-century "seamstress" half-blinded by her travails and championed by Oscar Wilde in "The Happy Prince" as well as John Ruskin's testimony in The Nature of Gothic to the repetitive, torturous labor of the men compelled to manufacture such beads ${ }^{36}$ Ophelia herself is rendered sightless by a white blindfold; this gaze cannot be mutual or collaborative, because the subject cannot see. At the same time, however, the brilliant beads of Relief blind or dazzle the viewer and allow us to "revision" (to return to Rich's term) women's history and ekphrasis. Lou's sculptures now command thousands of dollars: this is intermedia feminist art that works materially to enrich the artist as well as culturally to historicize women's artistic production.

Covered in gold leaf and bedecked with Swarovski crystals and semi-precious stones, Liz McGrath's resin and fiberglass bust The Eyes of Dead Ophelia (2004; also called "Ophelia") comments through its media upon the historical tendency to value women as beautiful or precious-seeming objects and for that value to increase when women are passive, commodified — or dead. The bust is deliberately grotesque in its culturally feminine aspects: its staring golden eyes, mermaid-like hair, shiny, smooth, white "skin" and puffy lips. For a Shakespearean, the transformation of the dead body into precious stones recalls Ariel's "ditty [that] does remember

${ }^{34}$ Holland Cotter, "Art in Review: Kiki Smith," New York Times, April 12, 2002, accessed June $1,2013$.

${ }^{35}$ Liza Lou, quoted in Jan Garden Castro, "American History Is Not What It Appears to Be: A Conversation with Liza Lou," in Sculpture: A Publication of the International Sculpture Center 22.4 (May 2003), accessed June 1, 2013. 
[Ferdinand's] drowned father" in The Tempest, in which the eyes of (not-)dead Alonso become pearls, his bones become coral and his whole body transforms "Into something rich and strange," or the anguished dream-recollection of the doomed Duke of Clarence, where dead men's skulls at the bottom of the sea lie amid anchors, gold, jewels, "and in the holes / Where eyes did once inhabit, there were crept / --As 'twere in scorn of eyes--reflecting gems. ${ }^{37}$ McGrath collected the precious stones to embellish Ophelia while on tour with her rock band; although known as an artist, she suggests that "art is how I make my living, but music is my passion." 38 As a selfportrait, then, the bust of Ophelia self-consciously refers to women as artists and to the history (personal, in this case) of its cultural production and its enmeshment in other forms of art.

\section{Gertrude Installs Ophelia}

More serious in its form and its political concerns than the earlier works I have described, Nalini Malani's mixed media image Hamlet (2005) presents, she writes, the Indian subcontinent, unable to decide "which way to go." ${ }^{39}$ She engages differently and at greater length with the notion of India as Hamlet in her intermedia video installation Hamlet Machine (1999-2000, revived 2010), inspired by Heiner Müller's Hamletmachine, which I discuss below. First,

${ }^{36}$ Oscar Wilde, "The Happy Prince," in A House of Pomegranates / The Happy Prince and Other Tales (London: Methuen, 1908), 171-2; John Ruskin, On the Nature of Gothic Architecture (London: Smith and Elder, 1854), 11.

${ }^{37}$ William Shakespeare, The Tempest, ed. Barbara Mowat and Paul Werstine, Michael Poston, and Rebecca Niles (Folger Shakespeare Library: Folger Digital Texts, accessed May 28, 2015), 1.2.483, 1.2.479; William Shakespeare, Richard III, ed. Barbara Mowat and Paul Werstine, Michael Poston, and Rebecca Niles (Folger Shakespeare Library: Folger Digital Texts, accessed May 28, 2015), 1.4.30-32.

${ }^{38}$ Liz McGrath, quoted in "Alternative Press Celebrates 25 Years Of Music With Art," Huffington Post, October 7, 2010, accessed 20 May 2015.

${ }^{39}$ Nalini Malani, "Unity in Diversity," in Nalini Malani, ed. Seàn Kissane (Dublin: Irish Museum of Modern Art, 2007), 99. 
however, Malani's painting: mysterious, it features the circles or cylinders connected by a thick cord that appear through her many paintings as potentially an umbilicus, a set of gears, a rope tied with knots, or even the rotating translucent Mylar cylinders on which her work is painted and projected during some installations. None of the figures in Hamlet is instantly recognizable as any character from Shakespeare's play, nor is any of the action. Malani uses her typical muted browns, yellows, and greens, what Chaitanya Sambrani calls the "palette...of the flesh-- living, throbbing, bloated, clotted, suppurating and decomposing," apart from the blue circles and the vivid red water-smeared polka-dots on the dress of a kneeling figure in the foreground whose face is half-obscured by the prominent blue circles. ${ }^{40}$ The polka dots, Malani has said, are inspired by the work of Japan-born and -raised New York conceptual and avant-garde artist Yayoi Kusama, which lends itself to feminist commentary although Kusama herself maintains of her career, "I was only thinking about myself and my art, and not women's liberation." kneeling figure, half-human, half-animal (it has goats' horns and a tail), a bald figure that might belong to an infant, and a black shape in Western shoes populate the rest of the foreground. The middle ground contains two figures squatting like weightlifters or perhaps defecating (one appears to be squatting over a pit) and a distorted, mustard yellow human shaped figure with its head crooked to one side. The background contains one animal and one human face to the far right of the picture, in yellowish-green. The circles and chains suggest the connections among human beings of all gender identifications, social classes, and origins, and the animal or animal-

\footnotetext{
${ }^{40}$ Chaitanya Sambrani, "Shadows, Reflections, and Nightmare: The Art of Nalini Malani," in Nalini Malani, ed. Seàn Kissane (Dublin: Irish Museum of Modern Art, 2007), 29.

${ }^{41}$ Quoted in Dana Friis-Hansen, "Yayoi Kusama’s Feminism,” Art \& Text 49 (1994): 55.
} 
like figures, along with the muted earth tones of the image, evoke our connections and responsibility towards the non-human word. ${ }^{42}$

Malani's work extends the reach of feminism to global human concerns and politics.

Often she uses women's voices, women's work, and women's suffering in order to foreground the intransigent political and social problems of poverty in India. Her gripping Hamlet Machine dramatizes the 1993 destruction of the Babri mosque by Hindu fundamentalists, quoting an unnamed woman who cries out (like Ophelia, the voice of the repressed) "What are you doing to this country!" and including on the looped soundtrack what I assume is Malani's own voice saying, "I feed my own data into the computer." The four video projections, which themselves feature film projected on to the body of a Japanese Butoh dancer (and which according to some accounts include video from a production of Müller's play), loop continuously on three screens and on the floor for twenty minutes. ${ }^{43}$ The floor-screen of the room in which the installation takes place is covered with a layer of table salt that evokes Gandhi's famous Salt March. Recorded and titled voices speak over each other in Hindi and English to turn Müller's play about the partition of East and West Germany into a parable about the partition of India and to break down binaries (including the gender binary) in this stunning example of intermedia feminist art in its tenderly chilling appropriation of children's and women's suffering voices. Any "gaze" here is certainly collaborative and mutual; "gender-full and gender-free."44 Malani's installation defies categorization, especially in this piece that screens on the body of a Japanese

\footnotetext{
42 Nalini Malani, "Hamlet,” Mixed media, $<$ http://www.saffronart.com/common/zoomit.html?url=http://mediacloud.saffronart.com/auctions /2012/absnov/nalini_12ab_07807_hires.jpg>, accessed March 24, 2014.

${ }^{43}$ A segment is broadcast here on YouTube: $<\mathrm{http}$ ://www.youtube.com/watch?v=cEdgZXrGOxo>, accessed May 28, 2015.

${ }^{44}$ Sarah Ruddick, quoted in Liss, op. cit., 76.
} 
dancer, to the soundtrack of children's voices, filtered and colored black-and-white video of a German playwright's adaptation of an English classic text.

In hailing feminist intermedia artists as Gertrude, I aim to break down the false dichotomy between the two female characters in Shakespeare's play and to reframe their relationship (and by extension, the ties that bind women artists to one another) as loving rather than competitive. The representations above are third-person, as it were — but the dominant mode currently to represent Ophelia in art is through young women's photographed and computer-edited self-portraits widely and freely disseminated online. Shakespearean Alan Young summarizes the cultural anthropologist Michael Wesch to argue that young women's selfportraits as Ophelia on "Web 2.0" (including Flickr, Pinterest, YouTube and other sites of usergenerated creative content, curation, and collection) can offer both artist and viewer a new freedom and even a new humanity: "online [viewers] are permitted to stare unrestrictedly at their fellow human beings in ways not otherwise socially acceptable. The result is often the development of an appreciation of the beauty and humanity of others. There is a new and potentially beneficial kind of communication involved in this process." Young, however, continues: "However, it should be noted that while Wesch offers a positive interpretation of the viewing process, the more skeptical critic will no doubt see the viewer as engaged in an unhealthy voyeurism, and the objects of that voyeurism as narcissistic, self-promoting, and engaged in behavior that reduces the self and agency to sexual object." ${ }^{" 45}$ Indeed. Since Young and others have documented and continue to analyze Ophelia in fan-fiction and user-generated art, however, I will concentrate here on the work of the young professional Los Angeles artist Ellina Kevorkian, because it seems to me to participate in the same kinds of multi- or intermedia

${ }^{45}$ Alan Young, "Ophelia and Web 2.0," op. cit. 
synthesis, ironic commentary and methodological innovation as Malani's work even as its political anger concentrates more explicitly on sexualized women's bodies.

Kevorkian's portrait of her non-identical twin Soseh Kevorkian as Shakespeare's Ophelia and as what she calls (in an electronic mail message to this volume's editors) her own "psychic likeness" (in her Love Poems of Infidels) deploys feminist intermediality in multiple senses, as a visual ekphrasis that dramatizes and mocks sexual competition among women; as the ethical gaze that parodies female suffering as aesthetically pleasing; as the re-enactment of women's work and art within art itself — and in multiple material modes, using archaic, twentienthcentury, fine, and demotic methods of production and dissemination. Love Poems of Infidels as a whole parodies and restages well-known images by the Pre-Raphaelite Brotherhood and features the artist herself along with her twin sister to bring out concerns of women's identity and beauty along with the idea of twinning or duplication and mechanical reproduction. Each artwork is multiply remediated: first scripted and staged, blocked as a theatrical production; then photographed, digitally edited, and printed; then rendered by hand in acrylic paint. Kevorkian's Ophelia wears a peach bustier and diaphanous white western gown that recall Kate Winslet's garments in Kenneth Branagh's Hamlet. Ellina and Soseh in this artwork "reference the only other twins noted in [their] family; male train robbers from Texas a century ago," writes Ellina Kevorkian, who adds, “The costumes are literally made from our mother's curtains $[\ldots]$ hung in the bedroom Soseh and I shared as children through the 1970s [...in] a nod to the intergenerational teachings of feminism and Shakespeare, as it was our mother Karen Kevorkian, a poet, who provided us access to her Riverside Shakespeare." Posed in a white, ceramic bathtub with old-fashioned, heavy, steel faucets, the Kevorkians' Ophelia gazes fixedly in full make-up at the single flower she holds in her hand. Her knees are raised and her pudendum is unselfconsciously visible through her translucent gown. One side of the bathtub is overgrown 
with realistic-seeming foliage (some taken from Millais's image directly); the other abuts pixelated circles in cyan and magenta, like a computer-game from the 1980s. Both Ellina and Soseh are essential to the project, writes Ellina, because the latter, "trained in performance, brought the sense of theatricality to the paintings that was required." ${ }^{46}$ Here is the decentered or collaborative gaze; the self-referential incorporation of women's artworks, women in artworks, and the historiography of women artists; and human, capacious tenderness in scale and subject.

\section{Gertrude speaks Ophelia}

We can find a feminist intermedia artistry in Gertrude's elegy to Ophelia in Shakespeare's text itself, although this feminist history has been camouflaged on the one hand by the speech's frequent extraction and placement in anthologies and on the other by the smoothing out of its textual irregularities. Deanne Williams' recent essay on the stage direction in Q1, "Enter Ofelia with a Lute," similarly foregrounds primary printed texts of Hamlet in order to uncover what I would identify as an intermediality that is potentially feminist: the interlude, and the stage direction, suggests Williams, presents the aesthetic skill of a woman artist with "time and space to express herself, and to be heard." ${ }^{\text {47 I }}$ offer here a diplomatic transcription of Q2 (1604), from the British Library copy, which I use as my copy-text, indicating Folio readings in square parentheses.

There is a Willow growes ascaunt the [aslant a] Brooke

${ }^{46}$ Ellina Kevorkian, Personal Communication (electronic mail message to Ania Loomba and Melissa Sanchez), September 15, 2015.

${ }^{47}$ Deanne Williams, "Enter Ofelia With a Lute," in The Afterlife of Ophelia, op. cit., 124. 
That showes his horry [hore] leaues in the glassy streame,[:]

Therewith fantastique [There with fantasticke] garlands did she make [come]

Of Crowflowers [Crow-flowers], Nettles, Daises [Daysies], and long Purples

That liberall Shepheards giue a grosser name,[;]

But our cull-cold maydes [cold Maids] doe dead mens fingers [Dead Mens Fingers] call them.[:]

There on the pendant boughes[,] her cronet weedes [Coronet weeds]

Clambring to hang,[;] an enuious sliuer broke,

When downe her [the] weedy trophies[,] and her selfe

Fell in the weeping Brooke, her clothes spred wide,

And Marmaide like awhile [Mermaide-like, a while] they bore her vp,

Which time she chaunted snatches of old laudes [tunes],

As one incapable of her owne distresse,

Or like a creature natiue [Natiue,] and indewed [indued]

Vnto that elament, [Elament:] but long it could not be[,]

Till that her garments[,] heauy with theyr [her] drinke,

Puld [Pul'd] the poore wretch from her melodious lay [buy]

To muddy death. (Mv)

On the level of content, the speech corresponds to Liss's "maternal mourning" in its incorporation of the lost child's (Ophelia's) artistic production into the woman-speaker/artist's utterance/performance. ${ }^{48}$ The first line of the speech presents perhaps its best known crux; does the willow grow "ascaunt the Brooke" or "aslaunt a Brooke"? Q2's "ascaunt" or askant derives

${ }^{48}$ For an excellent and thorough, if idiosyncratic, reading of the speech in linear, grammatical, exhaustive detail, see the poet Stephen Ratcliffe's Reading the Unseen: (Offstage) Hamlet (New York: Counterpath Press, 2010). 
from "askance," a sidelong glance, and thus begins the personification of the "horry" or "hore" (hoary, white-haired, that is, silvery-leaved) weeping willow as an "envious" elderly husband eager to pull his young wife down out of a tree (as if old January from Chaucer's "Merchant's Tale" suddenly took his revenge on youthful May only to fall a-"weeping" with remorse afterwards). Gertrude memorializes Ophelia's "weedy trophies" not so much to emphasize the latter's insanity through an off-kilter value-system (weeds cannot be valuable and hence cannot be trophies) but in order to emphasize the process and labor through which weeds can become trophies or prizes. The word "Clambering" appears as the catch-word in Q2, as if Ophelia clambers from the foot of one page to the top of the next (and it's worth recalling that until the Pre-Raphaelites dominated imagery of Ophelia, she had overwhelmingly appeared upright, active, and "clambering" to secure her garlands, as in the late eighteenth-century oil-painting by Mary Hoare, now in the Yale Center for British Art). Here is the clear-eyed, ironic and complete picture of the child at work, focused and rapt. Note, too, that Ophelia's garlands are "fantastique" — an adjective that commentators take to describe pathological delusion but that more commonly refers to phantasy, the essential early modern brain power that orders overwhelming sensory impressions into coherent ideas and perceptions, and that shapes imagination into art. Q2 gives us "Therewith...did she make"; F, "There with...did she come," a substantive variant, since "Therewith" would mean, "She made fantastic, imaginative garlands out of the Willow leaves with other flowers" and "There with" would mean, "She brought to the glassy stream fantastic garlands of flowers" fabricated by someone else, or by Ophelia at a different time (the periphrastic auxiliary, "did she" could suggest either habitual action in the past or sustained action in the recent past, immediately prior to her drowning). Q2's "make" emphasizes the process of fabrication; $\mathrm{F}$, the space for this artistic expression and, perhaps, its premeditation. The Quartos attribute the name "dead mens fingers" to "cull-cold maydes," but the Folio gives 
"cold maydes," an emendation that usually stands. "Cull" is a Cotswold term for a Bull-head fish, however, so the phrase "cull-cold maydes" connotes the slimy chill of the water and prefigures Ophelia's “mermaid-like” demise. As Stephen Ratcliffe points out, the "pendent” or hanging bough associates (through the figure of necklace or earring) Ophelia's cronet or coronet (“crownet") with Gertrude's own crown and the corona of the flowers she gathers, although he seems unaware that in fact OED gives "coronet," "corona" or "crownet" as synonyms for the distinctive flowering of umbelliferous plants (crow-flowers are ranunculaceae, nettles are urticaceae, and long purples are archideaceae, but Ophelia's earlier bouquet contained "fennel," which does grow in coronas or ring-like clusters of blossoms).

"Weeping," as many have noted, is a transferred epithet from the willow and perhaps from the speaker; "mermaid-like" modifies both Ophelia and the wake of her garments, billowing around her as a fish's tail. Ratcliffe notes that we do not hear the "old lauds" or "old tunes" that Ophelia sings — even suggesting that Gertrude figuratively stops Ophelia's breath by failing to tell us what the "snatches" of overheard melody were — and joins with earlier commentators to find Gertrude, if not guilty, then at least complicit in the concealment of Ophelia's murder by a person unknown. ${ }^{49}$ But I find in that crux "lauds/tunes" another way to read Gertrude's speech. "Lauds" are songs of praise and magnification, and Gertrude's speech attempts to ascribe glory and significance not just to Ophelia's death but also to her power as artist or creator. Liss suggests that feminist art that incorporates maternal mourning can do so through collaboration with the dead child and through an engagement with children's work; Pigman and others suggest that early modern maternal elegy aims to memorialize dead children and young adults by ascribing coherent identities to them, since their lives had not yet taken form. Katie Normann Grubbs suggests (in her dissertation-in-progress) that child and young-

${ }^{49}$ Stephen Ratliffe, op.cit., 72. 
adult elegies additionally share formal characteristics missing or scant in elegies for adults, including a predominance of lamentation (rather than praise or lauds), botanical detail, and figures of lending or redemption. ${ }^{50}$ If we contextualize Gertrude's horticultural references as elegiac, Ophelia becomes one of her own flowers, plucked too soon, and the pronominal confusion surrounding "the weedy trophies" and "her weedy trophies" and "garments heavy with her drink" or "their drink" (through a confusion of weeds, meaning wild flowers, and weeds, meaning clothing) unites girl, flower, and garment. Like Nature in Sonnet 126, water and willow are "envious" to win back their "native"-born (a figure used to justify or console grieving parents by suggesting that the child never belonged to them anyway).

Ophelia and the water become one as her clothing soaks through so that she is "endued" or en-dewed into the liquid around her. So at one, in Gertrude's imagining, is Ophelia with the brook that it is not the water that drowns her but the mud - the interstitial boundary between land and water - that murders her. Her "melodious lay" is the song (OED, lay n.4) she trolls, the lay or lake that she turns into performance space (OED, lay n.1) but also the breaking down of barriers between field and stream, lea and lay (OED, lay n.13). The water can "drink" her up and digest or "endue" her (OED endue, v. 2) painlessly, but when her earthly "garments...drink" the water, they "pull" her down to the bed of the stream.

Gertrude herself disappears during this speech. I suggest that we can find no rational explanation, diegetic or extra-diegetic, for her apparent witnessing of Ophelia's death, unless we take her seriously when she tells us that she thought of Ophelia as a daughter or a daughter-inlaw and that she grieves her loss. If we consider Gertrude's speech as feminist intermedia art that consecrates Ophelia's lost human capabilities, we realize that she did not need literally to witness

\footnotetext{
${ }^{50}$ Katie Normann Grubbs, "The Child-Elegy in Early Modern English Literature," Dissertation (director Christy Desmet), University of Georgia, in progress.
} 
Ophelia's drowning, because the speech testifies not to Ophelia's death (which Gertrude breaks to Laertes before her speech directly and, moreover, must repeat again after her speech in response to Laertes' "Alas then she is [is she] drownd") but to Ophelia's life and creativity. Gertrude's gaze is neither voyeuristic nor culpable, but collaborative and capacious. It directs us to imagine the inner lives of others as nuanced, rich, and creative; it directs us to feminism. 